\title{
A Review of Green Building Development in China from the Perspective of Energy Saving
}

\author{
Ying Zhang ${ }^{1,3} \mathbb{C}^{\mathbb{D}}$, Jian Kang ${ }^{1,2, *}$ and Hong Jin ${ }^{1}$ \\ 1 School of Architecture, Harbin Institute of Technology, Harbin 150001, China; \\ rourou_heaven@126.com (Y.Z.); hongjin777@sina.com (H.J.) \\ 2 Institute for Environmental Design and Engineering, The Bartlett, University College London, \\ London WC1H 0NN, UK \\ 3 Urban Construction Research Institute of Heilongjiang Province, Harbin 150001, China \\ * Correspondence: j.kang@ucl.ac.uk or j.kang@hit.edu.cn
}

Received: 8 December 2017; Accepted: 29 January 2018; Published: 2 February 2018

\begin{abstract}
This paper reviews the history of green building development and assessment standards in China, particularly from the perspective of energy saving. It is divided into four parts: (1) the development of policies of green building in China that have been proposed for meeting energy-conservation and emission-reduction targets; (2) the scientific research on green building by the Chinese government, including the promotion of maximum resource sustainability, environmental protection, and the reduction of pollution; (3) the development of assessment standards for green building in China; and (4) the development of green building technologies in China.
\end{abstract}

Keywords: energy-saving; history of green building; assessment standard

\section{Introduction}

In the 1970s, there was an energy crisis in which Earth's resource supply and environmental health became an increasingly serious problem. At that time, people began to rethink the values of the industrial era and re-adopted the green thinking of ancient agricultural civilizations. China's building consumption accounts for approximately one-third of all social energy consumption [1], and the environment has a substantial impact on the natural environment, human health, and the social economy [2], leading to discussions of energy conservation, green building and environmental sustainability issues, and their practical significance.

Reviews of research on the development of China's green building practices, usually with time trends as the main presentation style, summarize typical events and their influence on the development of green building. This paper provides a summary analysis of the development process and the effectiveness of the factors associated with green building.

The development of green building in China is based on the constant stimulation of government policy, the constant innovation of scientific research, continuous improvement in the standard system, and continuous technological innovation. Therefore, from the perspective of energy savings, this paper reviews the history of green building in China from the four perspectives of policy development, scientific research, the assessment standard system, and technological innovation, and analyses the effects of implementation and effects on energy savings.

\section{The Development of Green Building Policies in China}

\subsection{The Initiation of Green Building in China}

The initiation of sustainable development can be traced back to the 1960s, when the concept of ecological architecture was proposed. From the perspective of contemporary green architecture, 
most ancient Chinese buildings are quasi-green. Ancient people adopted the basic principles of the "sustainable utilization of resources" and "take what you need and spare the rest" [3], the essence of which is to oppose the destructive exploitation of resources, and to advocate for the limited development and utilization of resources to achieve their sustainable use. This is the earliest traceable green thinking in Chinese culture.

Reform and opening accelerated the industrialization of China and caused a surge in energy demand, increasing China's dependence on external "energy imports". In the primary energy structure of China, the consumption of coal accounted for $68.8 \%$ of energy produced, and petroleum gas accounted for 3.1\%, demonstrating that in general, China remained in the coal age [4]. Early Chinese construction was generally practical, but it was difficult to adapt to industrial changes. Construction did not consider basic insulation problems or account for outdoor environments in the hot summer and cold winter, making buildings difficult to update [5]. In China's northwest region, people used local natural resources, such as natural soil and natural building materials, facilitating both research and practical breakthroughs through the use of simple processes and indigenous materials. These methods afforded convenient sampling, low costs, and simple construction processes. The construction itself saved both cultivated land and energy in conformity with the current "energy saving, land saving" national policy. Adobe buildings, rammed earth buildings, cave buildings, and other architectural forms [6] were the typical types of China's construction technology, based on local conditions, and were the first form of green building in China.

The idea of green building came later in China than in developed Western countries, and energy problems associated with ongoing urbanization are gradually emerging. With the first "international green building conference" held in Beijing in 2005, China's green development model gradually matured. At the end of 2016, China had selected more than 4500 green building assessment identification projects, accounting for more than 500 million $\mathrm{m}^{2}$ of green buildings. By $2020,50 \%$ of new residential buildings will comply with the green building standard, and the Chinese market will gradually enter a period of large-scale development [7].

\subsection{Policy Support for Green Building in China}

The earliest work related to building energy conservation in China began in the 1980s. In 1979, the environmental protection law of the People's Republic of China was enacted (trial implementation), and the Provisional Regulations on energy conservation management were enacted in 1986, outlining clear requirements for building design measures to reduce energy consumption. Because China had promulgated policies and regulations to reward individuals or enterprises that had contributed to the comprehensive utilization of resources, a convention on building energy efficiency, policies and regulations was proposed [8]. In 1987, the United Nations Environment Programme issued a statement on sustainable development that greatly encouraged the development of an energy conservation movement. Architects, green movement groups, and the public quickly accepted the idea of sustainable development to develop and improve their theories, methods, and practices.

In 1992, the United Nations Conference on the environment and development was held in Rio De Janeiro, Brazil, during which 183 countries co-signed the Twenty-first Century Agenda, which brought environmental, economic, and social concerns into a single policy framework. This agenda was of epic significance, and was recognized as an "action plan for worldwide sustainable development". Attention has gradually shifted to building energy consumption, land occupation, resource consumption, indoor and outdoor environmental concerns, and so on. Foreign green building technologies and research results gradually affect China. The sustainable development of architecture has become a matter of consensus between the government and industry. Exploratory development through government investments and international research projects provided the theoretical basis of China's green building policy. A comprehensive design that includes architecture and the environment should be made from the ecological standpoint to achieve orderly results, promote recycling, and coordinate symbiosis with the environment [9]. In 1993, China became an importer of oil and a "freshman" in the club of the world's oil-consuming countries, late by nearly a century. The Chinese government proposes the comprehensive utilization of "industrial wastes". 
By encouraging the policy and scope of green building, China has promoted green building from a sporadic and spontaneous experimental state to the administrative level. In the face of the energy crisis, the Chinese government recognizes the importance of solving the energy crisis, changing the energy structure, and most importantly, advocating favorable measures for energy conservation [10].

From the initial concept of basic energy savings to enhance the renovation and development of wall materials, the promotion of household savings of energy, land, water, and materials generated the concept of "four savings and one environmental protection", which gradually appeared in the development of green building in China. In 2002, the United Nations passed two important documents at the World Summit regarding sustainable development to improve both the global economy and the status of social sustainable development. Soon after, China first mentioned "strengthening green building technology", and the term "green building" began to appear in government documents, opening the way to encourage green development [11].

The first international green building conference was held in Beijing in 2005. Thus, a development strategy that was oriented towards saving energy, advocated the development of green building, and established a sustainable development mode as the core of a low-carbon economy which made these elements the prerequisites for Chinese architecture and environmental development [12].

With the deepening of its commitment to green development, China will increase its energy savings and reduce its emissions as a national strategic policy [13]. The Ministry of Finance has issued relevant documents and other policies, urging both the government and other departments (such as the reform, technology, planning, and government affairs departments) to strengthen coordination (mainly with policy incentives), mobilize enthusiasm to accelerate the development of green building, and guide the healthy development of green building [14]. China also issued a series of green building standards and additional regulations. The national economic and social development planning outline for 2011-2015 formally proposed that the construction industry promote green building and green construction, and green building was first written into China's national plan. In 2012, the Ministry of Finance, the Ministry of Housing and urban rural construction companies jointly published opinions about accelerating the development of green building in China [15]. Local governments of first-tier cities in China developed economic green building incentives, and the growth rate of green building in China is accelerating. Green building has become a key factor in the construction industry. As the Chinese change their methods, this period has been described as "the rapid advance of urbanization and the development of strategic opportunities" [16]. In 2013, Chinese government departments jointly issued a "green building action plan", after which the national Chinese green building action officially kicked off [8].

\section{Scientific Research on Green Building in China}

Because of the energy crisis, China promotes sustainable development and develops circular goals for its population, resources, the environment, and development, which are necessary to consider the needs of both current and future development. The academic view has become a politician's action. The Chinese government has adopted energy conservation and the reduction of emissions in China's basic national policy, and included an outline of that policy in the national technical development plan [17]. In the key areas of "urbanization and city development", a priority theme of "energy-efficient building and green building" is listed. This priority theme focuses on the development of green building design technology, energy saving technology and equipment construction, the integration of renewable energy devices and application technology, exquisite construction and green building construction technology and equipment, energy-saving building materials and green building materials, and building energy-saving technical standards, etc., to establish national science and technology research programs [18].

The "National medium and long-term Science and Technology Development Program (2006-2020)" in the "Urbanization and urban development" key areas listed "Building energy efficiency and green building" as priority issues. The foci of research and development are green building design technology, building energy-saving technology and equipment, renewable energy devices and building integration technology, exquisite construction and green building construction technology and equipment, 
energy-saving building materials and green building materials, and building energy-saving technical standards [18]. Using the development plan for national science and key technology research as an example, theme projects and topics related to green building include the following: "Research on the key technologies of green building", "Research on the key technologies of modern architectural design and construction", "Research and development of assessment systems and standard specification technology on green building", "Research and integration demonstration of key technology systems for green building planning and design", "Research and demonstration of key technologies of transformation of existing green buildings", "Research and demonstration of key technologies for green energy-saving of public institutions", "Research and engineering demonstration on the integration of western eco-towns and green building technology", "Research and application of the post-assessment method of green building performance based on actual operation effect", "New methods and tools for effect-oriented green building design", and so on [8].

The Ministry of Construction and the Ministry of Science and Technology jointly undertake the "Tenth Five-Year" project. They perform key technology research in green building, primarily in the areas of green building planning design guidelines, the structural systems of green building, green building materials technology research and assessment systems. In addition, to reduce the water consumption of buildings, they perform research to reduce building energy consumption and perform other comprehensive key technology research, along with research on indoor environmental pollution, green building, green matching, and improving technology research and other related issues [19]. The Chinese government has included the goal of saving energy and energy utilization in the national "11th Five-Year" and "12th Five-Year" projects, considering modern architectural design, the construction of green technology, and related issues of green building design throughout the life cycle of key technologies [20]. In the "13th Five-Year" plan for building energy conservation and green building, Chinese developments included improving building energy efficiency standards, increasing the proportion of new buildings in towns to promote green building, constructing energy-efficient transformations, and gradually expanding the application of renewable energy to a construction scale. The policies are intended to make building projects greener and theme subjects to propose new research directions [21].

In addition, in 2017, work plans will include topics such as "New methods and demonstration of regional climate adaptability for green public building design", "Green building technology model and technology systems based on multiculturalism in the western region", "Green building system inheriting the Chinese architectural context in developed areas", and "The implementation of data management technology based on the entire process", which are key special projects of green building and building industrialization to be implemented [8].

Therefore, the research and development of green building technology in China not only has attracted increasing support, but also has been studied by professional researchers. "Four savings and one environmental protection" that existed in the early years is studied comprehensively for different stages of the building life cycle, including evaluation, planning, design, construction, and reconstruction in recent years, strongly supporting China's green building technology integration and innovation. In the future, research and development will be based on geographical and architectural characteristics that are to be further refined, and will be more concerned about the actual effect of green building and operation performance, better promoting and implementing the green concept. In 2016, joint departments issued guidance in the "National Science and Technology Plan to Strengthen the Technical Standards in the Implementation of Special Research Work", strengthening interactive support for the standardization and innovation of science and technology, enhancing the level of technical standards in science and technology innovation, promoting the level of standards through scientific and technological innovation, and promoting the transformation and application of scientific and technological achievements with standards [8].

Table 1 lists the roles or relationships of assessment standards or codes of green buildings for different periods in China. 
Table 1. The roles and relations of standards or codes.

\begin{tabular}{|c|c|c|c|}
\hline No. & Types & Standard or Code & The Role of Standard or Code \\
\hline 1 & \multirow{4}{*}{ Guidance } & $\begin{array}{l}\text { Chinese Ecological Residential Technology Assessment } \\
\text { Handbook (2001) }\end{array}$ & \multirow{4}{*}{ To supplement, improve, and guide the standards or codes issued during each period. } \\
\hline 2 & & $\begin{array}{l}\text { The Technical Essentials for Construction of Healthy } \\
\text { Housing (2001) }\end{array}$ & \\
\hline 3 & & Green Building Evaluation Technology Conditions (2007) & \\
\hline 4 & & $\begin{array}{l}\text { Green Building Evaluation Identity Management } \\
\text { Method (2007) }\end{array}$ & \\
\hline 5 & \multirow{2}{*}{ For Beijing Olympics } & $\begin{array}{l}\text { Assessment System for Green Building of Beijing } \\
\text { Olympic (GOBAS) }\end{array}$ & \multirow{2}{*}{ To guide the construction of the Beijing Olympic Games. } \\
\hline 6 & & $\begin{array}{l}\text { Implementation Manual of Green Building for } \\
\text { Beijing Olympics }\end{array}$ & \\
\hline 7 & \multirow{4}{*}{$\begin{array}{l}\text { For every link in } \\
\text { the building }\end{array}$} & Code for Green Building of Civil Building (2010) & $\begin{array}{l}\text { Design is a key link in the whole life cycle of architecture. It dominates the influence of each stage } \\
\text { of building on resources and environment. It is of great significance to promote the development } \\
\text { of energy-saving and land-saving residential buildings and public buildings. }\end{array}$ \\
\hline 8 & & $\begin{array}{l}\text { Evaluation Standard for Green Construction of } \\
\text { Building (2010) }\end{array}$ & $\begin{array}{l}\text { Promote green construction, standardize the evaluation method of green construction for building } \\
\text { engineering, and develop the standard. }\end{array}$ \\
\hline 9 & & Code for Green Construction of Building (2014) & $\begin{array}{l}\text { Improve the utilization rate of building materials, promote the improvement of construction } \\
\text { engineering management level, and promote the benign development of construction enterprises. }\end{array}$ \\
\hline 10 & & $\begin{array}{l}\text { Technical Code for Operation and Maintenance of Green } \\
\text { Building (2016) }\end{array}$ & $\begin{array}{l}\text { Operation and maintenance, as the longest stage of construction, is an important link in the life of } \\
\text { the building. The code is effective and profitable. }\end{array}$ \\
\hline 11 & \multirow{6}{*}{$\begin{array}{l}\text { For different types } \\
\text { of buildings }\end{array}$} & Evaluation Standard for Green Industrial Building (2013) & $\begin{array}{l}\text { The development of green industrial buildings and assessment of green industrial buildings can } \\
\text { collect important basic information of building energy consumption and water consumption, and } \\
\text { provide important data support for formulating more comprehensive energy saving indicators. }\end{array}$ \\
\hline 12 & & Evaluation Standard for Green Office Building (2013) & $\begin{array}{l}\text { Improve the assessment system of green building in China, and guide and promote the } \\
\text { development of green office building. }\end{array}$ \\
\hline 13 & & Assessment Standard for Green Store Building (2015) & $\begin{array}{l}\text { Improve the assessment system of green building in China, and guide and promote the } \\
\text { development of green store building. }\end{array}$ \\
\hline 14 & & Evaluation Standard for Green Hospital Building (2016) & $\begin{array}{l}\text { Compared with other types of buildings, hospital buildings have high performance requirements, } \\
\text { strict environmental requirements, and different functional requirements. It is necessary to } \\
\text { compile green building evaluation standard specifically for hospital buildings. }\end{array}$ \\
\hline 15 & & Assessment Standard for Green Hotel Building (2016) & $\begin{array}{l}\text { Improve the assessment system of green building in China, and guide and promote the } \\
\text { development of green hotel building. }\end{array}$ \\
\hline 16 & & $\begin{array}{l}\text { Assessment Standard for Green Museum and Exhibition } \\
\text { Building (2016) }\end{array}$ & $\begin{array}{l}\text { It is of great significance and promotion for the whole society to pay attention to energy saving } \\
\text { and environmental protection by promoting the development of green expo building. }\end{array}$ \\
\hline
\end{tabular}


Table 1. Cont

\begin{tabular}{|c|c|c|c|}
\hline No. & Types & Standard or Code & The Role of Standard or Code \\
\hline 17 & For existing building & $\begin{array}{l}\text { Assessment Standard for Green Retrofitting of Existing } \\
\text { Building (2015) }\end{array}$ & $\begin{array}{l}\text { Improve the technology of green transformation and the system of products, and promote the } \\
\text { development of green reconstruction of existing buildings. }\end{array}$ \\
\hline 18 & \multirow{3}{*}{$\begin{array}{l}\text { For green building and } \\
\text { healthy building }\end{array}$} & Assessment Standard for Green Building (2006) & $\begin{array}{l}\text { The first national standard on green building. With the green building work step by step, the } \\
\text { connotation and extension of green building have been continuously enriched. Various industries, } \\
\text { various places, and various types of construction demand for green ideas to be put forward. } \\
\text { However, this standard cannot fully meet the needs of green building practice and assessment } \\
\text { work at the present stage. }\end{array}$ \\
\hline 19 & & Assessment Standard for Green Building (2014) & $\begin{array}{l}\text { On the basis of old standards, the scope of evaluation objects is extended, the evaluation stage is } \\
\text { clear, the evaluation method is more scientific and reasonable, and it is synchronized with the } \\
\text { international community. The evaluation index is more systematic and perfect, taking full account } \\
\text { of China's national conditions. }\end{array}$ \\
\hline 20 & & Assessment Standard for Healthy Building (2016) & $\begin{array}{l}\text { China's healthy building is based on green building. With the green building as the starting point, } \\
\text { balance the performance, outstanding health is the optimal choice. }\end{array}$ \\
\hline
\end{tabular}




\section{Development of Assessment Standards for Green Building in China}

\subsection{Emergence of Assessment Standards for Green Building in China}

In China, the standardization of green residential building was developed as recently as 15 years ago. The "Chinese Ecological Residential Technology Assessment Handbook" was written and published, providing technical guidance for ecological residential assessment. In 2001, "The Technical Essentials for the Construction of Healthy Housing" was published, and "Healthy Housing Construction Technology Points" was issued. With China's successful Olympic bid, the idea of a green, high-technology Olympics was proposed. The Chinese government and industry jointly designed the "Assessment System for Green Building of the Beijing Olympics" and the "Implementation Manual of Green Building for the Beijing Olympics", which were published one after the other. They are the research results of national projects including the "Green Olympic Building Assessment System", which outline the construction of the Olympic park, venue, and other various buildings [22]. The Chinese construction ministry issued a series of energy saving design standards for new residential buildings, green building guidelines, and other notices $[8,23]$.

The promotion of green building in China is not limited to government and research institutions, but also to prospective developers, owners, and design organizations. The 2006 "Assessment Standard for Green Building" is a comprehensive assessment standard for green building that summarizes practices and research results. It is the first international attempt to develop a multi-objective, multi-level, and comprehensive assessment standard of green building established according to the "four savings and one environmental protection" core content [24,25]. Next, the Centre of Science and Technological Development of the Ministry of Housing and Urban/Rural Development established the green building evaluation and identification management office, which is primarily responsible for managing green building evaluation marks, accepting green building evaluation marks, and guiding one- and two-star green building evaluation and identification activities. From the beginning of this period, the work of evaluating green building has been performed [26].

In 2007, "Green Building Evaluation Technology Conditions" was released. That same year, the "Green Building Evaluation Identity Management Method", which outlines China's energy strategy and green building development, was officially promulgated [8]. A number of relevant Chinese departments jointly stated that their focus is an emphasis on "a combination of energy conservation and technology innovation", which improves the technical standards system, improves building energy efficiency standards, promotes the existing building energy efficiency transformation, promotes green building and green building materials, and deepens the application of renewable energy building [27]. Based on the assessment standard for green building, the Chinese government and experts summarized the practice and research results. In the next 10 years, more direct services for green building national and industry standards have been released, and the implementation of a green building standards system has gradually improved. These standards include the "Code for green building of civil buildings", "Evaluation standards for green construction of buildings", "Evaluation standards for green industrial buildings", "Evaluation standards for green office buildings", the "Code for green construction of buildings", "Assessment standards for green store buildings", "Assessment standards for green retrofitting of existing buildings", "Evaluation standards for green hospital buildings", "Assessment standards for green hotel buildings", "Assessment standards for green museums and exhibition buildings", "Technical codes for operation and maintenance of green buildings", etc. [28]. In addition, with the gradual progress of promoting green building work, the connotation of "green building" is constantly enriched, and the demand for green ideas is continually updated in various industries, places, and for various types of buildings. Based on the revision of "Assessment standards for green building" in 2006, the 2015 version "Assessment standards for green buildings" was formally implemented [8]. 
Based on people's need to pursue a healthy life, in the gradual maturation process of green building, healthy building has become the strategic demand for a healthy China. The "Assessment Standard for Healthy Building" that introduced this standard drives and powers the development of China's green building industry [8].

\subsection{Effectiveness of the Assessment Standards System for Green Building in China}

In the period of economic development, China's green, energy-saving buildings were built from scratch, and the construction industry accounts for many of the changes in total energy consumption. As shown in Figure 1, which is based on data and statistics from the national database [29], the government vigorously developed energy-saving, emissions-reduction policies to promote the rate of green building construction at the beginning of the 20th century. The energy saving effect of the construction industry is significant, and the changes in the construction industry accounted for the yearly decrease in total energy consumption (aside from a slight increase in 2006 and 2007). For the 2008 Olympic Games in Beijing, China promoted green development to cater to the idea of a "Green Olympics". During this period, the energy consumed by construction was significantly reduced, after the period in which the development of green energy-saving building was accelerating. With the use of new, highly efficient energy sources, such as hydropower, renewable resources, natural gas, and other energy sources, energy efficiency increased, and the energy consumption ratio continued to rise in the construction industry.

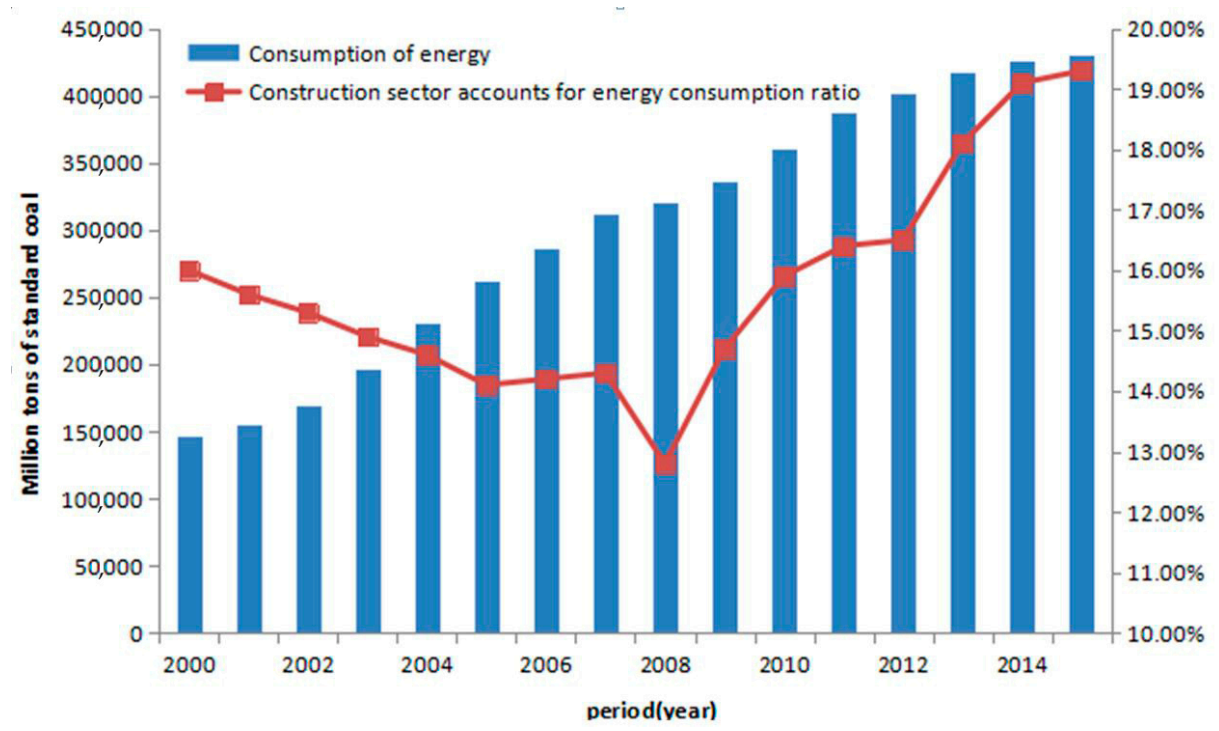

Figure 1. Consumption of energy and the proportion of energy consumption by the construction sector in China from 2000 to 2015.

With the rapid development of China's economy, the growth rate of the gross domestic product (GDP) surpassed 7\%, and the "building era" had already begun. The number of new construction projects in China has increased rapidly, and the scale has become increasingly large. As shown in Figure 2, which is based on data and statistics from the national database [30], for housing construction from 1996 to 2000, the completion of small-amplitude projects has increased steadily since the 20th century. The rate increased year by year, reached a maximum in 2014 and 2015, and then decreased slightly. After that, the construction completion period steadily moved towards sustained growth. Alternatively, it can be seen in Figure 3 that from 2008 to 2016, the number of China's green building star-labelling projects changed. It increased rapidly starting in 2008, reached a maximum in 2013 and 2014, and decreased in 2015. "Technical Guidelines and Key Points in Construction for Green Ecological Housing Estate" was promulgated in 2002. The Chinese government and industry sector 
promulgates technical standards for green building each year to provide a technical basis for green building, which advanced quickly, except in 2008 and 2009. The construction of green buildings is increasing. The number of green-building projects in the provinces of China are shown in Figure 4; this information was obtained from the digital green building map network [30]. The first project location is Jiangsu Province, followed by Guangdong Province. The number of projects in the other provinces is also in an incremental state.

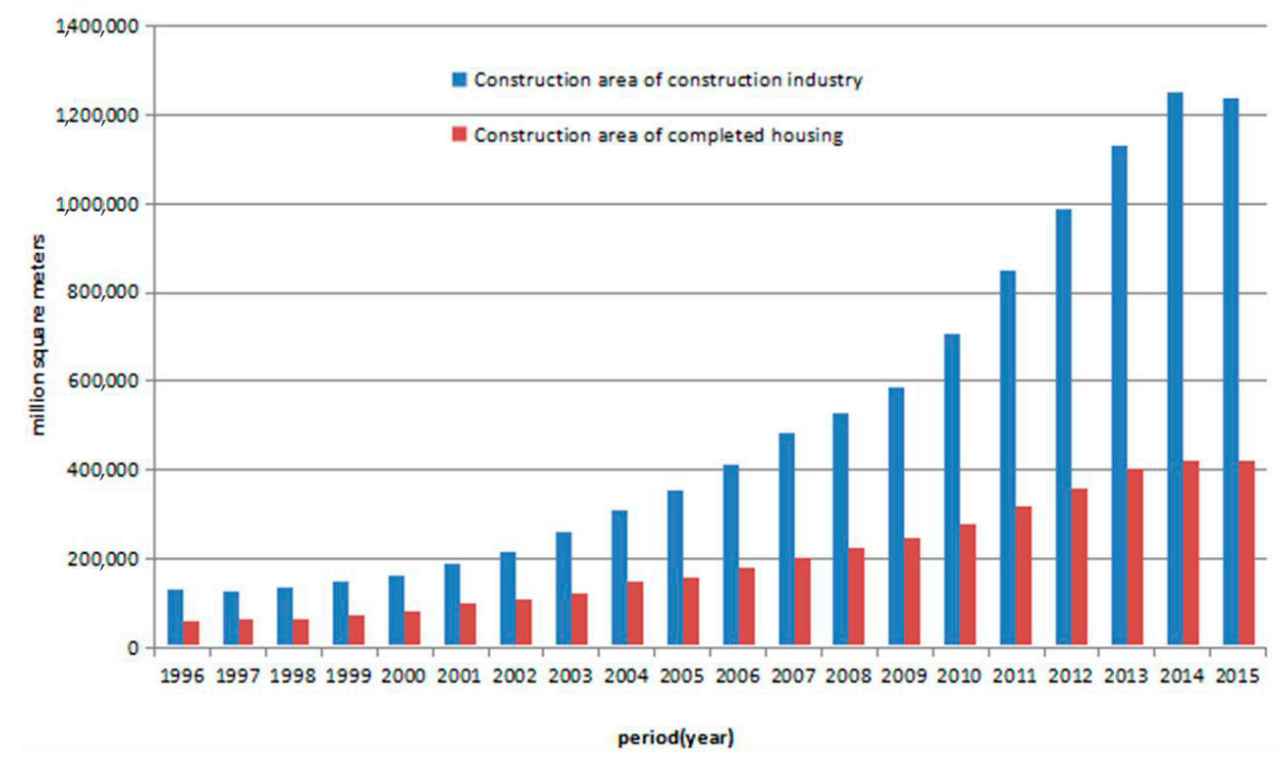

Figure 2. Construction area of the construction industry and completed housing in China from 1996 to 2015.

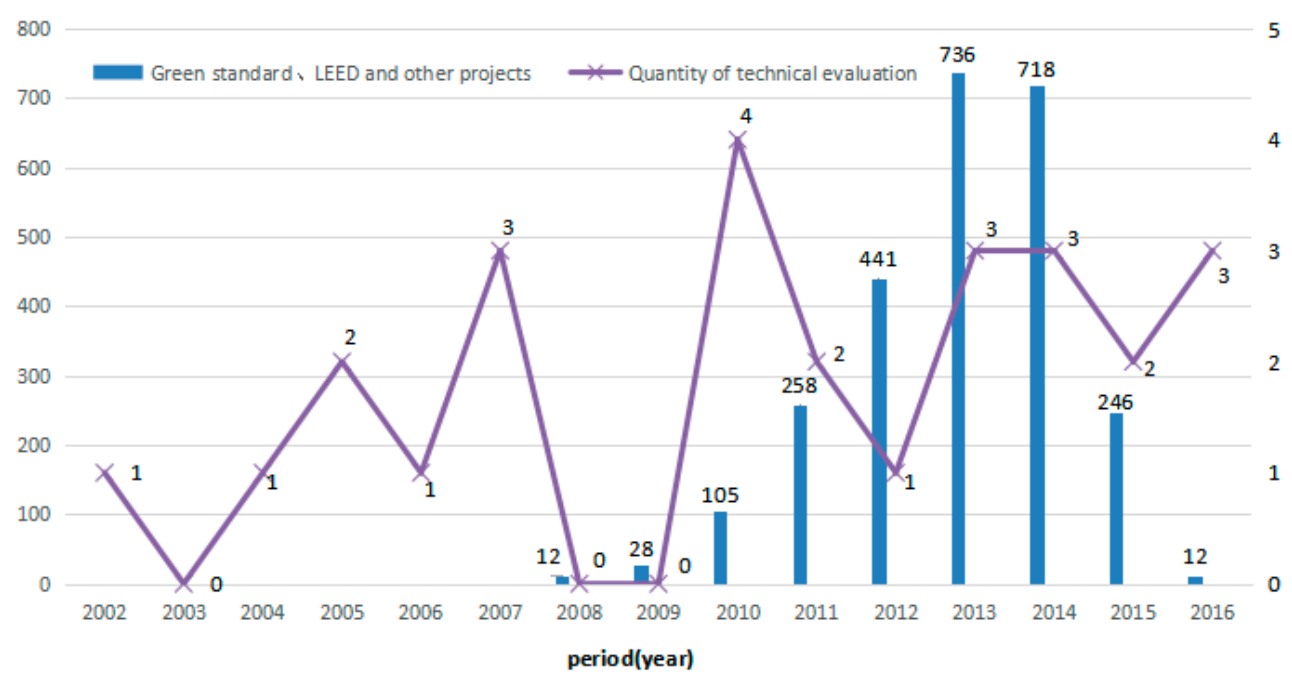

Figure 3. The number of star labelling projects in green building and technical evaluation standards in China from 2002 to 2016. 


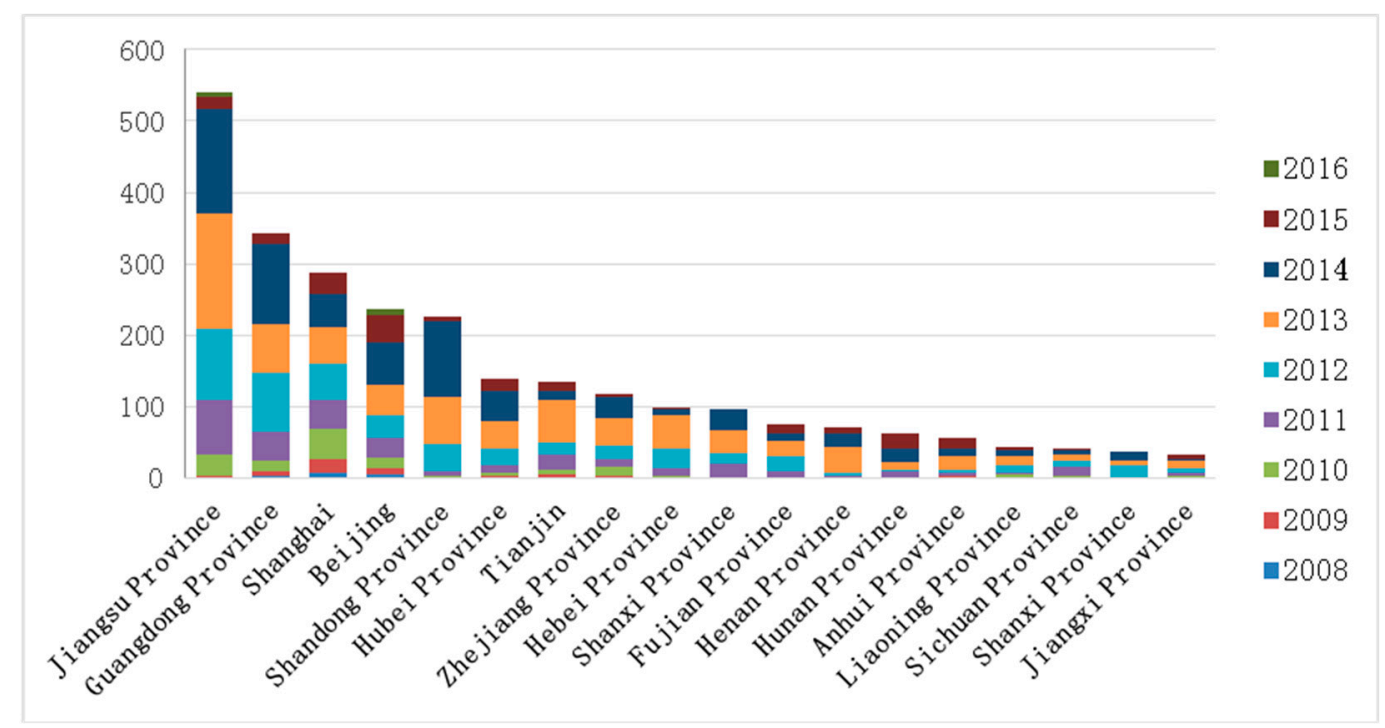

Figure 4. Provinces and cities at the forefront of green building projects in China.

\section{Development of Green Building Technologies in China}

\subsection{Research Progress of the Basic Theory}

In 1972, the United Nations held the first International Conference on Human Environmental Issues in Stockholm, and published the declaration of the UN Conference on the Human Environment, which marked the awakening of global environmental awareness. Domestic low-carbon cities boomed with the developmental trends in global green energy saving. Experts and scholars began to reflect from different perspectives, inquiring into a new type of building industry, taking into account the thermal performance of building materials, the energy efficiency of HVAC equipment, renewable energy and other technical issues as the starting point. They laid a foundation for the suitability of key technologies, using material innovation as the starting point, for building energy and green building development [31-47].

People's living standard has been improved and their quality of life has been improved. Green building began to enter into life, as it advocates healthy and comfortable living environments, and sustainable use of resources [48]. Construction environments integrated with the surrounding environment could contribute to the pollution reduction of building life cycle emissions, thus, to reduce the negative effect on the natural environment [49]. Based on the whole life cycle theory, building energy consumption can be divided into building process energy consumption and building energy consumption. In order to reduce the energy consumption of the whole life cycle of buildings, one can start from two aspects: one is to reduce the energy consumption related to the building ontology, and the other is to reduce the energy consumption in the process of building construction [50]. Figure 5 shows the proportion of energy consumption in the life of the building [34].

In terms of energy saving and reducing emissions, solutions were proposed, such as metering reform in China, new building energy-efficiency standards, large-scale public building energy saving, full decoration of housing, promoting prefabricated construction, applying renewable energy in buildings, demonstrating green building, and extending existing problems [51]. In the face of environmental pollution and energy consumption, by analyzing building data, experts and scholars became aware of the nature of the materials that were used in the construction process, which should be used without prejudice to their environmental impact, with sustainable development as the goal of human settlement in China. Therefore, they promoted research on green building systems, establishing a basic idea for China's green building system [52-54]. 


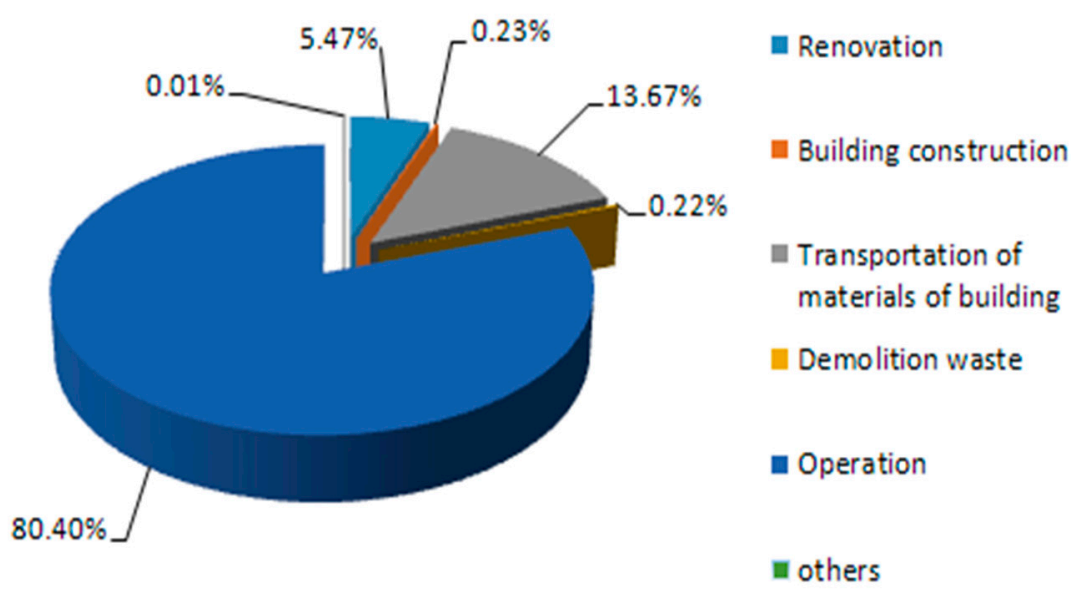

Figure 5. The proportion of energy consumption in the life of the building.

As noted above, this paper summarizes the development process of green building theory. Accordingly, it discusses the importance of exploring technological innovation in practice. From the "four savings and one environmental protection" perspective, green building development in China has experienced a period of exploration. Following a series of innovations, building technology activities increased the speed of construction, while considering the conservation of building materials. At first, the activity remained within a reasonable range of building technology. However, innovation activity is tested by construction quality, and has forced people to reconsider the construction of security in the construction field. Once political influence faded, the economic impact became dominant [55]. The original China was completely cut off from the West, which ushered in foreign exchange after the reform. China is attempting to gradually adopt the techniques and forms of Western architecture, and to understand and follow cutting-edge trends in the architecture of more advanced countries. The government began to pay attention to the architects' overseas exchanges and study tours, and through the study of methods and channels of China's building contacts with the outside world, Chinese building technologies ushered in fresh thoughts and mature experiences [56].

\subsection{Technological Innovations in Energy Conservation and Energy Utilization in Green Building in China}

The energy-saving technology of building in China is primarily focused on two aspects of a building, including the enclosure structure and equipment system, which includes doors, windows, roofs, floors, and walls. The traditional buildings of China have wooden window forms, which have a high requirement for heat preservation, heat insulation and sound insulation around the building. The form of the window gradually evolved into the steel window, the aluminum window, the aluminum wooden window, and so on, in which thermal insulation performance greatly increased. Window glass includes single glass, double insulation glass, hollow glass, Low-E glass, etc. [57]. To meet the requirements of the new standard, roofing insulation must have an energy-saving design that emphasizes lightness and efficiency, has low to no water absorption, and facilitates the long-term use of stable performance insulation materials as an insulation layer. Improving the roof structure is conducive to of moisture [58]. Regarding the use of energy-saving technology in the ground, insulation is enhanced by making contact with the floor, where the surrounding ground insulates, and does not heat the upper floor of the basement [58].

Most of the buildings that were built in China before 2000 are non-energy efficient; their external walls merely maintain the structure and their chosen material rarely conforms to the energy-saving factor. Table 2 shows examples of the traditional wall and the modern wall, where the changes of the thickness, thermal resistance, and heat transmission coefficient of the envelope structure can be seen. Compared with the current situation in China, before 2000, the wall thickness is greater, but the thermal resistance is less, and the wall heat storage capacity was generally not satisfactory. With the 
development of the technology of external wall insulation and application of thermal insulation materials gradually, the thickness of wall has been reduced, saving materials, and the thermal resistance has been increased, leading towards considerable energy savings. With the energy-saving concept and the promotion of green building, China implemented higher energy and new construction requirements for existing buildings, which generally correspond to the emergence of mature wall insulation and energy-saving materials and energy-efficient new buildings.

Table 2. The traditional wall and the modern wall.

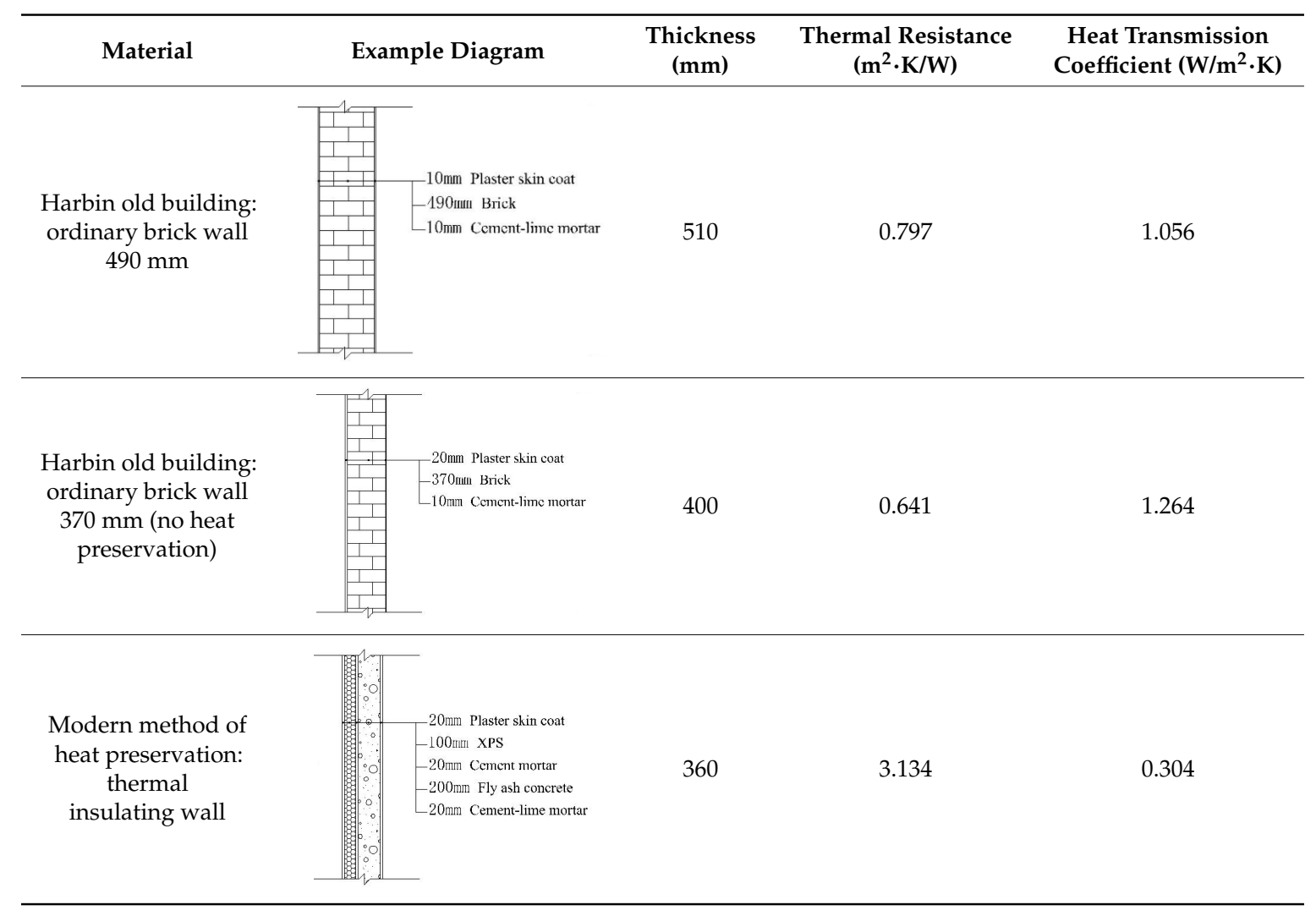

The goal of increasing energy efficiency is to reduce energy consumption by the building itself and to improve the efficiency of heating (air conditioning) systems. China's heating technology developed rapidly under the guidance of "energy conservation and development". Three categories of this technology can be identified, according to their energy consumption situations: northern towns, towns in the Yangtze River Basin, and rural buildings. The main measures of energy saving in a heating system are as follows: improving boiler thermal efficiency, adjusting the hydraulic balance and pipe insulation, and so on. In the past ten years, through the efforts of Chinese scientific research, design, operation and management personnel, remarkable economic and social benefits have been attained [58]. In addition, the energy-saving technologies associated with air-conditioning systems include ice storage technology, heat pump technology, and solar adsorption air conditioning, demonstrating that these technologies can achieve good economic benefits under suitable conditions [59].

The application technology of building energy saving in China also involves building equipment energy saving, building green lighting, and operation management optimization. From the initial coordination of regional features and local climate conditions, there is a gradual optimization of the use of low-energy consumption technology, including passive energy saving technology and the mechanical ventilation of natural ventilation, natural lighting, shading, etc., based on the full use of renewable energy, including solar, wind, biomass, and other sources of heat [60]. 


\subsection{Other Technical Innovations of Green Building in China}

In the past 20 years, China has gradually shifted its focus from building energy efficiency to green building, and green building is a higher-level goal of the sustainable development of buildings. In addition to energy saving, green building requires water saving, land saving, and material saving. Its essence is to improve the utilization efficiency of energy resources [61].

In past urban planning and construction, China did not pay attention to ecological construction and did not consider the principles of biodiversity; as a result, some practices violated the laws of nature. With the rise of the concept of land saving, construction began to prioritize the use of urban and rural waste land, turning waste into a benefit, and improving the urban environment while avoiding demolition and resettlement issues [62]. At the same time, environmental noise control, outdoor wind environment optimization, outdoor thermal environment optimization, and rainwater storage, garbage collection and treatment, and soil treatment, had higher requirements [63].

China is a country with severe droughts and water shortages. In past city planning and construction, China did not pay attention to water pollution. This not only generated abundant impermeable ground, but also caused higher losses of city wetlands. This is because the groundwater was inadequate, and land lost water to evaporation, adjusting the climate and aggravating the degree of water pollution [62].

The design principles and concepts of water-saving and water resource utilization in China's green building are self-sufficiency, striving for zero emissions, making full use of natural rainwater, and reusing reclaimed water to achieve the purpose of saving resources, using water resources, and protecting the environment [64]. In the process of promoting green building, from the artificial construction of roads, parking lots, square grounds, and so on, China is considering adopting a permeable pavement design, combined with increased permeability associated with landscape storage infiltration pools, seepage wells, and green space. This facilitates buildings and communities having the ability to maintain and retain rainwater, to absorb part of the flood volume, and to augment the low quantity of water. Technical research is also focused on the promotion of rainwater recharge, collection and utilization systems, and the study of reusing low-cost, high-safety technology systems for regional and large-scale water resources while ensuring water quality, and water health and safety [62].

The building material is the material base of architecture, and a brick, a tile, an iron, and a stone on the building are solid forms of energy and resources. A large amount of $\mathrm{CO}_{2}$ is emitted in the production and manufacturing processes. In China, every $1 \mathrm{~m}^{2}$ of building can be used to produce $50-60 \mathrm{~kg}$ of steel and $0.2-0.23$ tons of concrete, or $0.15-0.17$ tons of brick [62], which will produce a substantial amount of waste. In the process of promoting green building, saving materials is an important control index that is primarily reflected in the stage of architectural design and construction [65]. There are several important perspectives on the development of wood-saving technology in China: reusing existing structures and materials, thereby reducing the production of these materials, energy consumption, and the amount of transportation of building materials; reducing the generation of construction waste, using materials for regeneration, such as wood, etc., and recycling waste generated during construction, operation, and demolition; and preferentially using local building materials [65].

\subsection{Practical Projects of Green Building Technology in China}

As China's green building theory has become clear, green energy-saving technology has been applied, and China's green building market has matured. Economically developed areas in China have begun to mature, using the results of the study on green building theory, combined with their own urban characteristics associated with the key technology of green building system integration and application. A series of model buildings, energy-efficient models of the community and ecology became the basis of China's earlier green building technology, education, and the promotion of its research and development platform. 
In 2002, the Tsinghua University ultra-low energy consumption test building was constructed; the project was finished in 2005. The project's $1000 \mathrm{~m}^{2}$ of office building can be integrated with most types of building energy-saving technology, becoming China's first example of energy-saving technology and its most comprehensive, extensive, and innovative demonstration. It is well known in building energy-saving industries, and it is the model for promoting and popularizing the knowledge and technology of building energy conservation [66]. In 2004, the Shanghai Academy of Building's eco-built office building was constructed; it used a variety of new technologies and new products, and an architecture integration design. It had natural ventilation, natural lighting, ultra-low power consumption, healthy air conditioning, renewable energy, green building materials and intelligent control, resource recycling, an eco-green and comfortable environment, and other technical characteristics. The comprehensive energy consumption of the building is only $1 / 4$ of that of comparable buildings. Whereas other buildings' renewable-energy use accounts for $20 \%$ of their total energy use, the Shanghai Academy of Building's renewable resource utilization reaches $60 \%$, and it has a healthy and comfortable indoor environment. The scale of the building is small, based on English and American green building standards, but it is still under study, and the subject of experimentation. From the functional point of view, it is already a more complete green building [67]. In 2005, the Shenzhen Merchants Real Estate Tiger used state-of-the-art technology and products to obtain LEED (Leadership in Energy and Environmental Design) Silver certification, becoming China's first commercial green building project [68]. In addition, the 2005 Operational Research Centre at the Ministry of Science and Technology of the 21st century is China's first LEED gold certification program. In 2008 and 2009, a Chinese three-star green building project named the SANYO plant renovation project received investment. The Shenzhen Vanke Centre and Shenzhen branch building in Shenzhen were built at approximately the same time, but they have their own characteristics. They are nearly $20,000 \mathrm{~m}^{2}$ in size, built in the style of a market, and have completely surpassed experimental architecture [69].

Green buildings have greatly contributed to technological advances, and the construction market is more energy saving, efficient, and recyclable. Considering the actual resources and environment of China during the initial period of green technology, the Chinese government can only open buildings to energy-saving with Chinese characteristics in accordance with the concept of scientific development, changing policies of advanced technology obtained from developed countries to establish Chinese characteristics and mechanisms to achieve the efficient use of energy.

Compared with the international "green" thought, the understanding of green building in China is still in the primary stage. Before the realization of the modern green value, people can learn from technology. In the long run, whether the green building will be able to play its due value in its survival and use will face many challenges [70].

However, in developing a positive situation, the fields of energy saving, emissions reduction, and the development of green building in China have also exposed some problems. The number and distribution of projects in China, the development of green buildings compared to pilot demonstrations, and increased initial investment costs are characteristic of the "light green" development stage. However, because of the difference in cognitive support-related groups, awaiting mature technology and influenced by the lack of a system, Chinese green building has not fulfilled higher-level requirements in establishing different groups of integration mechanisms, advocating appropriate technology concepts, formulating grass-roots consumer demands, and so on. Emphasis on local conditions and problem orientations should be the core starting point of green building technology organizations [70].

\section{Conclusions}

Energy conservation, the development of green building, and the promotion of sustainability are mutually developed processes. Chinese green building has experienced ten years of development from the understanding of the importance of sustainable energy, the foreign energy crisis, and domestic 
environmental problems, learning from advanced foreign exploration of the technology of green building. The Chinese government and scholars jointly promote this difficult stage of development, boosting both the generation and the maturity of the theory, but in practice, they continue to encounter problems, such as technology, philosophy, benefits, and other contradictory conditions. Energy-saving technology with Chinese characteristics and green building development remain in a critical period of maturity.

The maturity of Chinese green building is the common result of the transformation of people's ideas and technological progress, including policy, existing theory, technology, and other aspects. The Chinese government has established rules and regulations, technical specifications, and incentive policies to ensure the quality of green buildings, promoting enthusiasm for green buildings in society. A Chinese green building standards system forms the project stage and the main functional types of the system itself, but the standards for assessing green building in China have no "foundation", and lack interdependence. In terms of technology and theory, China's government and industry have been studied by relevant technical organizations. Key technology breakthroughs have been achieved in the areas of energy saving, water saving, land saving, material saving, and building environment improvement, and some research results have been achieved, gradually popularized, and applied widely.

The essence of green building is the conservation of resources, based on the concept of sustainable development and the type of design and construction used. The theory and technology of green building in China have certain limitations. From the perspective of energy conservation, green building in China pays attention to local conditions, is people-oriented, and maximizes the benefits of Chinese characteristics. Green building in China is maturing.

Acknowledgments: This work was financially supported by the National Natural Science Foundation of China (Grant Number: 51438005).

Author Contributions: Ying Zhang, Jian Kang and Hong Jin conceived the paper and design the review study; Ying Zhang collected and consulted the relevant references and data, and analysed the data; Ying Zhang drafted the paper; Jian Kang, Hong Jin and Ying Zhang revised the paper.

Conflicts of Interest: The authors declare no conflict of interest.

\section{References}

1. Wei, J.Y.; Yan, W.G.; Yao, Z.M. Present situation of energy consumption and potentiality saving on energy of building in China. J. Shenyang Archit. Civ. Eng. Inst. 1994, 4, 185.

2. Ji, Y.Y. Green Building and Energy Saving Technology; Qingdao Technological University: Qingdao, China, 2014; p. 2.

3. Zhao, A.Q.; Liu, N. A review of the simple green ideas of Chinese ancient architecture. J. Xi'an Univ. Archit. Technol. (Soc. Sci. Ed.) 2010, 3, 36-40.

4. Thinking about China's Energy Structure. Available online: http://xianhuo.hexun.com/2012-10-25/ 147224682.htm (accessed on 20 September 2017).

5. Yang, J.B. Comparative analysis of China's first five year plan and the Soviet Union first five year plan. Stat. Commun. 1955, 8, 5-11.

6. The first academic meeting summary of the Architectural Society of Chinese cave and adobe building. Archit. J. 1981, 10, 29-30.

7. Wang, Q.Q. Promoting green building development. Learn. Times 2017, 7, 1 .

8. China Academy of Building Research. Review and Prospect of Green Building Standard in China; China Architecture \& Building Press: Beijing, China, 2017; Volume 7, pp. 1-41.

9. Liu, X.J. A new subject of eco architecture in the development of modern cities. Archit. J. 1981, 2, 9-14.

10. Guo, R.S. Agenda 21: Action and prospect. China Popul. Resour. Environ. 2012, 5, 5-8.

11. Niu, W.Y. The theoretical connotation of sustainable development-The 20th anniversary of UN conference on environment and development in Rio de Janeiro. China Popul. Resour. Environ. 2012, 5, 9-13.

12. Editorial Department. China green building decade. Constr. Sci. Technol. 2014, 6, 1. 
13. Notice of the State Council and the State Council on printing and Distributing the Plan of Energy Saving and Emission Reduction in 12th Five-Year ([2012] 40). Available online: http:/ /www.nea.gov.cn/2012-08/ 22/c_131800277.htm (accessed on 8 October 2017).

14. Qin, Y.G. Chinese Condition Must Be Considered on Developing Green Building in China; Springer: Berlin/Heidelberg, Germany, 2013; Volume 6, p. 15.

15. Ministry of Housing and Urban Rural Development, Ministry of Finance. Opinions on Accelerating the Development of Green Building in China (Financial Construction [2012] 167). Available online: http:/ / www.mohurd.gov.cn/zcfg/xgbwgz/201205/t20120510_209831.html (accessed on 8 October 2017).

16. Qiu, B.X. Development prospects and countermeasure suggestions of green building in China. Constr. Technol. 2011, 6, 10-12.

17. Yu, J.J. Sustainable development of population and environment in China. Univ. Forum 2013, $173-174$.

18. State Council of the People's Republic of China. The National Plan for Medium and Long-Term Science and Technology Development (2006-2020); State Council of the People's Republic of China: Beijing, China, 2006; p. 2.

19. People's Republic of China. The Outline of the Tenth Five-Year Plan for National Economic and Social Development; Theory and Contemporary: Guizhou, China, 2001; pp. 31-48.

20. The Twelfth Five-Year Plan for National Economic and Social Development of People's Republic of China. Available online: http:/ / www.gov.cn/2011lh/content_1825838.htm (accessed on 10 October 2017).

21. People's Republic of China. The thirteenth five-year plan for national economic and social development. In People's Daily; 2016; pp. 1-30.

22. Jiang, Y.; Qin, Y.G.; Zhu, Y.X. Assessment system for green building of the Beijing Olympics for green positioning. Constr. Sci. Technol. 2003, 12, 68-69.

23. Li, Y.N.; Yang, L.; He, B.J.; Zhao, D.D. Green building in China: Needs great promotion. Sustain. Cities Soc. 2014, 11, 1-6. [CrossRef]

24. Lin, B.R. Assessment standard for green building: Indoor environmental quality. Constr. Sci. Technol. 2015, 4, 30-33.

25. Lin, H.Y.; Cheng, Z.J.; Ye, L. Interpretation of assessment standard for green building. Constr. Sci. Technol. 2013, 6, 64-66.

26. Qin, Y.G.; Lin, B.R.; Zhu, Y.X. Research on assessment standard for green building. Archit. J. 2007, 3, 68.

27. Zhang, J.G.; Gu, L.J. Challenges and policy recommendations of the green building development in China. China's Energy 2012, 12, 19-24.

28. Notice of the Ministry of Urban and Rural Construction on Issue of the 13th Five-year Plan for the Development of Building Energy Conservation and Green Buildings JianKe [2017] No. 53. Available online: http:/ / www.mohurd.gov.cn/wjfb/201703/t20170314_230978.html (accessed on 10 October 2017)).

29. Wang, Q.Q.; Meng, C.; Li, G.Z. Development demands and prospect of healthy buildings. Heat. Vent. Air Cond. 2017, 7, 32-35.

30. National Bureau of Statistics of the People's Republic of China. Available online: http:/ / data.stats.gov.cn/ index.htm (accessed on 1 November 2017).

31. Green Building Map Network. Available online: http://www.gbmap.org/ (accessed on 1 November 2017).

32. Ministry of Housing and Urban-Rural Construction of Building Energy-Saving and Notification of Division on Elements of a Published Work in 2017 JianKe Comprehensive Letter [2017] No. 17. Available online: http:/ / www.mohurd.gov.cn/wjfb/201703/t20170323_231232.html (accessed on 1 November 2017).

33. Lan, K.; Li, Q.M. A study of the development of UK's green architecture. J. Xi'an Univ. Archit. Technol. (Soc. Sci. Ed.) 2012, 6, 29-33.

34. Li, L.M. The Study on the Green Building Assessment System; Tianjin University: Tianjin, China, 2003; pp. 1-2.

35. Wu, Z.Q.; Deng, X. The first of strategies of Chinese green building: Overall Composition of the Straegy. Urban Hous. 2008, 4, 66-69.

36. Wu, Z.Q.; Deng, X. The second of strategies of Chinese green building: Formation process. Urban Hous. 2008, 4, 66-69.

37. Qin, Y.G. Green buildings under China's actual conditions. Chin. Foreign Constr. 2005, 3, 4-5.

38. Gou, Z.H.; Shen, J. Intelligent building envelope with integrated green technology. Huazhong Archit. 2007, 9, 78-80. 
39. Lin, H.Y.; Wang, Q.Q. Enhancing technology research and promoting scale development of green building in China. Constr. Technol. 2014, 5, 10-13.

40. Liu, J.P.; Wu, L.Y. New energy utilization in architectural energy conservation and design. New Energy Technol. 2001, 2, 12-15.

41. Liu, S.Y.; Yang, F. Two strategies of adaptive transformation of old buildings: Renewal of building functions and innovation of energy consumption technology. Archit. J. 2007, 6, 60-65.

42. Zhang, X.L. Passive house:ideal buildings with high comfort and ultra-low energy consumption. Constr. Technol. 2012, 10, 66-70.

43. Yin, J.Q.; Chen, B.; Chen, T.D.; Song, L.; Kang, J. Design of whole life cycle green buildings and human living environment. Urban Dev. Stud. 2015, 1, 1-5.

44. Sun, S.J.; Jin, H.; Zhao, Y.D. Details of insulation wall. J. Harbin Univ. Civil Eng. Archit. 2002, 8, 84-86.

45. Gou, Z.H.; Lau, S.S.Y.; Chen, F.N. Subjective and objective evaluation of the thermal environment in a three-Star green office building in China. Indoor Built Environ. 2012, 21, 412-422. [CrossRef]

46. Gou, Z.H.; Prasad, D.; Lau, S.S.Y. Are green buildings more satisfactory and comfortable? Habitat Int. 2013, 39, 156-161. [CrossRef]

47. Gou, Z.H.; Xie, X.H. Evolving green building: Triple bottom line or regenerative design? J. Clean. Prod. 2017, 153, 600-607. [CrossRef]

48. China Urban Science Research Association. Green Building in China (2013); China Architecture and Building Press: Beijing, China, 2013; Volume 4, pp. 1-15.

49. Zhang, Q.Y. Research on Whole Life Appraisal of Green Building; Tianjin University of Technology: Tianjin, China, 2008; p. 2.

50. Chen, W.K.; Luo, F. Research on building energy consumption based on whole life cycle theory. Build. Sci. 2008, 10, 26-27.

51. Qiu, B.X. From green building to low carbon eco-city. Urban Stud. 2009, 7, 2-10.

52. Qiu, B.X. Six fields with the largest building energy-saving potential and their outlooking in China. Archit. Technol. 2011, 1, 6-9.

53. Ye, Y.X. Architecture vision for the 21st century. Archit. J. 1997, 2, 38-40.

54. Liu, K.C. Green building system and research. New Archit. 1997, 4, 8-10.

55. Dong, J.H. The first five-year plan on the several problems of urban construction. Archit. J. 1955, 3, 1-12.

56. Lin, N. 60 years of Chinese architecture: Analysis of the development of the architectural creation I. Archicreation 2009, 6, 153-157.

57. Wang, L.Q. Energy Efficiency Design of Residential Building's External Window in Cold North Area; Tianjin University: Tianjin, China, 2007; p. 14.

58. Wang, L.X.; Dang, R. Building Energy Conservation; China Construction Industry Press: Beijing, China, 2009; pp. 92, 115, 138.

59. Zhao, D.L.; Hu, C.Y.; Bo, D.S.; Li, W.F. Building energy conservation technology status and development trend in China. Build. Energy Conserv. 2015, 3, 118.

60. Wu, S.X. Key points of green building technology and suggestions for implementing green building. Archit. J. 2011, 9, 2.

61. Zhang, J.G.; Gu, L.J. Development status, challenges and policy suggestions of green building in China. Energy China 2012, 12, 20.

62. Wu, S.X.; Zhao, Y.Z. Advancing green buildings, promoting energy saving and CO2 emission reduction and improving human inhabitation environment. Dynamic (Eco-City Green Build.) 2011, 12, 21-22.

63. Ye, L.; Cheng, Z.J. Overview on green building standards development. Build. Sci. 2016, 12, 9.

64. Wang, R.Z.; Mo, W.; Qian, Y.M. Application of measures for water saving and water resources utilization in design of green buildings. China Water Waste Water 2009, 7, 22.

65. Huang, X.L.; Sun, H.; Peng, B. Green building materials and utilization technologies of material resources. Green Technol. Summ. 2013, 1, 30-31.

66. Su, D.X.; Zhou, Z.N. Interpretation of ultra low energy consumption demonstration building of Tsinghua University. Archit. J. 2005, 9, 16-17.

67. Wang, D.K. Introduction of ecological and energy-efficient office demonstration building in Shanghai. Inaug. Semin. China's Energy-Sav. Refrig. Air Cond. Eng. Technol. 2006, 2, 82-89.

68. Fraser: Science and technology gave birth to green homes. Urban Hous. 2009, 2, 34-35. 
69. Zou, S.W.; Yu, Z. China architecture won the first international green building gold award. China Inf. News 2006, 4, 1 .

70. Huang, X.M. The challenges of the green building development in China. Urban Dev. Stud. 2015, 22, 3, 6. 